\title{
Kompetencje menedżera sprzyjające budowaniu pozytywnych relacji interpersonalnych
}

\section{Manager's competences to build positive interpersonal relationships}

\begin{abstract}
Streszczenie:
W artykule zaprezentowano kompetencje menedżerów, sprzyjające budowaniu pozytywnych relacji interpersonalnych w zespole. W obliczu współczesnych warunków gospodarowania w postaci globalizacji, organizacji wirtualnych i dominującej roli kapitału intelektualnego, sukces przedsiębiorstwa tkwi we współdziałaniu i wzajemności, które inspirują do wymiany doświadczeń i służą realizacji celów indywidualnych oraz zespołowych. Studia literaturowe i wyniki badań empirycznych potwierdzają wagę tych kompetencji, których posiadanie i ujawnianie podczas codziennej pracy przez menedżerów pozytywnie oddziałuje na pracowników.
\end{abstract}

Słowa kluczowe: kompetencje menedżera, pozytywne relacje interpersonalne, rola menedżera

\begin{abstract}
:
The article presents the competences of managers, conducive to building positive interpersonal relationships in the team. In the face of modern economic conditions in the form of globalization, virtual organizations and the dominant role of intellectual capital, the company's success lies in cooperation and reciprocity, which inspire to exchange experiences and serve the implementation of individual and team goals. Literature studies and the results of empirical research confirm the importance of these competences, the possession and disclosure of which during the day-to-day work by managers positively affects employees.
\end{abstract}

Keywords: competences of manager, positive interpersonal relationships, manager's role 
Ewa Podlewska - Kompetencje menedżera ...

\section{Wprowadzenie}

Współczesne uwarunkowania rynkowe odznaczają się dynamicznymi przemianami społeczno-gospodarczymi, które inicjują permanentne działania człowieka i organizacji. Nowe trendy i kierunki kształtują się również w obszarze zarządzania zasobami ludzkimi, eksponującymi kapitał społeczny jako strategiczny zasób organizacji. Aby sprostać wymaganiom nowoczesności i realizować długofalowe przedsięwzięcia niezbędna jest pozytywna atmosfera w pracy, inspirująca do wzajemnej współpracy i chęci współdziałania opartego na wymianie doświadczeń, zaufaniu oraz poczuciu bezpieczeństwa.

W perspektywie wyzwań współczesności można zaryzykować stwierdzenie, że w ciągu najbliższych kilkunastu lat relacje interpersonalne będą dominującą kwestią w procesie zarządzania. Ich kształtowanie się oraz dynamika zmian mogą stanowić klucz do sukcesów organizacji, ale także być źródłem niepowodzeń ${ }^{1}$. Pozytywne stosunki międzyludzkie wzbudzają zaangażowanie i zachęcają do partnerskiej współpracy. Natomiast ich negatywny wymiar może wpływać na niezrozumienie i utrudniać rozwój pracowników.

Zmieniające się otoczenie postawiło przed kadrą zarządzającą nowe wyzwania w postaci dostosowania zespołów do wymagającego rynku nowej ekonomii, a także podkreśliło rolę menedżera w budowaniu pozytywnych relacji interpersonalnych. Naturalność zmian ugruntowała też przekonanie, że organizacje muszą zmienić profil pożądanych kompetencji kadry zarządzającej, w tym posiadanych cech, prezentowanych postaw, zachowań oraz nabywanych umiejętności i wiedzy. Menedżerowie, którzy nie zdobędą odpowiednich

1 S. Guca, Zmiany w zarządzaniu i ich wpływ na kształtowanie się stosunków międzyludzkich, [w:] Wyzwania dla wspótczesnych organizacji w warunkach konkurencyjnej gospodarki, D. Lewicka, L. Zbiegień -Maciąg (red.), Kraków 2010, s. 281. 
kompetencji stanowić będą hamulec postępu, a zarządzane przez nich zespoły nie spełnią oczekiwań przedsiębiorstw² ${ }^{2}$.

Celem artykułu jest zaprezentowanie na podstawie przeglądu literatury i wyników badań empirycznych kompetencji menedżera, które nie tylko sprzyjają budowaniu pozytywnych relacji interpersonalnych, ale również warunkują zaangażowanie pracowników w realizowane czynności, przyczyniając się tym samym do sukcesu organizacji. Pożądane kompetencje bezpośrednich przełożonych zostały przedstawione w formie analizy komparatywnej, zarówno z perspektywy menedżerów, jak i z punktu widzenia pracowników.

\section{Kompetencje menedżera}

Zróżnicowanie warunków otoczenia oraz turbulentność zmian czynią koniecznym weryfikację priorytetów w zarządzaniu, a także uaktualnienie bądź udoskonalenie posiadanych kompetencji. Chociaż w nowych warunkach ekonomicznych zasadniczo nie zmienia się postrzeganie menedżera i w dalszym ciągu ponosi on odpowiedzialność za wyniki pracy oraz za zespół, ewolucji ulega jego świadomość, która wyznacza inne cele i odmienny sposób realizowania zamierzeń. Nadrzędną rolę odgrywają obecnie aspekty społeczne, umożliwiające kształtowanie właściwego środowiska pracy, stąd organizacje oczekują dziś menedżerów akceptujących wyzwania, kreatywnych i otwartych na doskonalenie kompetencji interpersonalnych ${ }^{3}$.

Zgodnie z definicją T. Rostkowskiego kompetencje to „zbiór wiedzy, uzdolnień, stylów działania, osobowości, wyznawanych zasad, zainteresowań i innych cech, które używane i rozwijane w procesie pracy

\footnotetext{
2 W. Karna, $W$ poszukiwaniu tożsamości menedżera przyszłości, [w:] T. Listwan, S. Witkowski (red.), Sukces w zarzq̨dzaniu. Problemy organizacyjno-zarządcze i psychospołeczne, Wrocław 2001, s. 186.

${ }^{3}$ M. Tyrańska (red.), Współczesne tendencje w zarządzaniu zasobami ludzkimi w przedsiębiorstwie, Warszawa 2010, s. 51.
} 
Ewa Podlewska - Kompetencje menedżera ...

prowadzą do osiągania rezultatów zgodnych ze strategicznymi zamierzeniami przedsiębiorstwa"4.

Znamiennym rodzajem kompetencji są kompetencje menedżerskie. Według T. Oleksyna oznaczają one zdolność do efektywnego, skutecznego i etycznego zarządzania. W literaturze przedmiotu wymienia się kompetencje menedżerskie pierwszego i drugiego stopnia 5 , wśród których umiejętności interpersonalne niezbędne do nawiązywania kontaktów, motywowania i stymulowania do wzajemnej współpracy odgrywają szczególną rolę $\mathrm{w}$ budowaniu pozytywnych relacji w zespołach pracowniczych.

Naukowcy zarządzania B. Becker, M. Huselid, D. Ulrich, krótko definiują kompetencje jako „wiedzę, umiejętności, zdolności lub cechy osobowości, które wpływają na pracę danej osoby"6. Określenie to jest spójne z punktu widzenia sprawności zarządzania, utożsamiającej kompetencje $\mathrm{z}$ "cechami podmiotu działania zrelatywizowanymi do sprawnego wykonywania określonego czynu, spełnienia funkcji w organizacji" 7 . Cele wyznaczone w artykule, skłoniły autorkę do wskazania konkretnych cech, postaw i zachowań, będących wyrazem pożądanych kompetencji menedżera, koncentrujących się wokół umiejętności budowania relacji. Obecnie pozytywne interakcje oznaczają bowiem nie tylko dobrą komunikację, ale skuteczność, odpowiedzialność i odwagę przy wprowadzaniu zmian.

Oddziaływanie indywidualnych cech na skuteczność działań determinuje sytuacja i nie zawsze można je adaptować do każdych warunków ${ }^{8}$. Nie jest więc wymierne wyodrębnienie samych cech efektywnego menedżera. Z punktu widzenia skuteczności jego pracy ważne są

\footnotetext{
4 T. Rostkowski, Kompetencje a jakość zarządzania zasobami ludzkimi, [w:] A. Sajkiewicz (red.), Jakość zasobów pracy, Warszawa 2004, s. 90.

5 J. Brilman, Nowoczesne koncepcje i metody zarzq̨dzania, Warszawa 2002, s. 398399.

6 B. E. Becker, Huselid, D. Ulrich, Karta wyników zarzq̨dzania zasobami ludzkimi, Warszawa 2012, s. 202.

7 T. Pszczołowski, Organizacja od dołu i góry, Warszawa 1978, s. 99.

8 K. Bednarz, Skuteczny przywódca. Cechy decydujące o powodzeniu organizacji, [w:] M. Pawlak (red.), Nowe tendencje w zarzadzaniu - uwarunkowania społeczne, Lublin 2013, s.69.
} 
elastyczne postawy i zachowania, które przyczyniają się do: budowania dobrych relacji, koncentracji na przyszłości, usuwaniu wewnętrznych barier we współpracy, rozwijaniu i doskonaleniu kompetencji oraz chęci dzielenia się wiedzą i doświadczeniem ${ }^{9}$. W oparciu o teoretyczne rozważania i empiryczne wyniki zaczerpnięte z literatury przedmiotu, autorka proponuje model cech osobowościowych menedżera, implikujących pożądane postawy i zachowania w kierunku budowania pozytywnych relacji, co przedstawia tabela 1.

Tabela 1.

\begin{tabular}{|c|c|c|}
\hline Cechy osobowości & Postawa kognitywna & Zachowanie \\
\hline Aktywność i energia & $\begin{array}{l}\text { Optymizm i pozytywne } \\
\text { nastawienie }\end{array}$ & $\begin{array}{l}\text { Dzięki osobistemu zaangażowaniu } \\
\text { stymulowanie do współpracy }\end{array}$ \\
\hline Empatia & $\begin{array}{l}\text { Wysoki poziom inteligencji } \\
\text { emocjonalnej }\end{array}$ & $\begin{array}{l}\text { Zainteresowanie indywidualnymi } \\
\text { osiągnięciami i problemami } \\
\text { pracowników }\end{array}$ \\
\hline $\begin{array}{l}\text { Otwartość } \\
\text { komunikacyjna }\end{array}$ & $\begin{array}{l}\text { Swoboda ekspresji w bezpo- } \\
\text { średnich kontaktach }\end{array}$ & $\begin{array}{l}\text { Aktywne słuchanie, partnerskie } \\
\text { relacje }\end{array}$ \\
\hline Szacunek & Uznawanie norm i wartości & $\begin{array}{l}\text { Kultura komunikatów werbalnych } \\
\text { i niewerbalnych, poszanowanie } \\
\text { godności }\end{array}$ \\
\hline Szczerość & Asertywność w komunikacji & $\begin{array}{l}\text { Otwarte wyznaczanie jasnych zasad } \\
\text { współdziałania, w tym system nagród } \\
\text { i kar }\end{array}$ \\
\hline Uczciwość & $\begin{array}{l}\text { Obiektywizm w ocenie } \\
\text { sytuacji }\end{array}$ & $\begin{array}{l}\text { Podejmowanie sprawiedliwych } \\
\text { decyzji; dotrzymywanie słowa } \\
\text { i obietnic }\end{array}$ \\
\hline Wiarygodność & Autentyczność w działaniu & Spójność zachowania, rzetelna praca \\
\hline Zaufanie & $\begin{array}{l}\text { Wiara w drugiego człowie- } \\
\text { ka, gotowość do polegania } \\
\text { na nim }\end{array}$ & $\begin{array}{l}\text { Dochowanie powierzonych tajemnic, } \\
\text { deinfluentyzacja, przekazywanie } \\
\text { uprawnień i delegowanie zadań }\end{array}$ \\
\hline
\end{tabular}

Źródło: opracowanie własne na podstawie dostępnej literatury.

${ }^{9}$ M. Tyrańska, Współczesne tendencje $w$ zarządzaniu zasobami ludzkimi, Warszawa 2012, s. 66. 
Ewa Podlewska - Kompetencje menedżera ...

W procesie budowania relacji najistotniejsze znaczenie posiadają cechy menedżera, które odnoszą się do bezpośrednio do niego, jako do człowieka, współpracownika. To one czynią priorytet ludzkiego współdziałania w skutecznym zarządzaniu ${ }^{10}$. Aby jednak prawidłowo reagować na sytuacje występujące w otoczeniu, zachowania menedżera nie mogą być tylko wynikiem jego cech osobowościowych, ale wymagają posiadania adekwatnych kwalifikacji oraz rzetelnej wiedzy popartej umiejętnościami.

Podstawą działania współczesnego menedżera są kompetencje relacyjne, ponieważ pozwalają wywierać pozytywny wpływ na ludzi, rozumiany jako zdolność do zmiany uczuć, poglądów i decyzji innych ${ }^{11}$, jeśli w dotychczasowym wymiarze uniemożliwiają realizację wspólnych celów. Oddziaływanie wyraża się w zachowaniu poprzez dawanie pozytywnych przykładów, a także $\mathrm{w}$ przekonywaniu opartym na wiarygodności menedżera. Czynnikiem ułatwiającym wywieranie wpływu jest serdeczne i życzliwe podejście.

Optymalny efekt pracy menedżera kształtującego pozytywne środowisko pracy zapewnia stosowanie wymienionych wyżej umiejętności uzupełnionych m.in. o umiejętności socjalne i komunikacyjne ${ }^{12}$. Pierwsze z wymienionych obejmują wiedzę o relacjach interpersonalnych i są niezbędne do kształtowania dobrych stosunków z pracownikami. Ich podłożem jest wzajemny szacunek, empatia i chęć identyfikowania autentycznych potrzeb pracowników. Umiejętności socjalne umożliwiają szybką reakcję na mogące pojawić się rozbieżności między oczekiwaniami pracowników a faktyczną ich realizacją oraz pomóc rozwiązać konflikty. Umiejętności komunikacyjne natomiast zapewniają sprawne przekazywanie informacji i jasne przedstawianie zadań, co prowadzi do wzrostu skuteczności oraz zadowolenia pracowników z tytułu poprawnie realizowanych obowiązków.

\footnotetext{
10 C. H. Barnard, Funkcje kierownicze, Warszawa 1992, s. 277.

11 G. Bartkowiak, Psychologia w zarządzaniu, Poznań 2010, s. 149.

12 Podstawowe umiejętności przełożonego 2001, „Zarządzanie na Świecie” 2001, Nr 2, s. 30-31
} 
Kompetencje odzwierciedlają potencjał menedżera, ale nie gwarantują efektywności bez umiejętności ich przełożenia na skuteczne działanie, praktyczne wdrażanie wiedzy i kształtowanie odpowiednich postaw.

\section{Istota pozytywnych relacji interpersonalnych}

Relacje interpersonalne odzwierciedlają wzajemne stosunki między ludźmi i odnoszą się do różnorodnych powiązań pomiędzy nimi. W typowym ujęciu obejmują dwa aspekty: psychologiczny i behawioralny ${ }^{13}$. Pierwsza z wymienionych perspektyw odnosi się do cech i postaw oraz predyspozycji partnerów, wynikających z ich osobowości, druga natomiast charakteryzuje relacje $w$ kontekście przejawianych zachowań i umiejętności ich budowania.

Podstawowym fundamentem i kreatorem relacji międzyludzkich jest człowiek, gotowy do autonomicznego działania na rzecz i razem $\mathrm{z}$ drugą osobą. Relacje kształtują się na bazie kontaktów z innymi ludźmi poprzez wymianę komunikatów, składających się z treści zasadniczej oraz komponentu relacyjnego, odzwierciedlającego emocje rozmówcy. W wyniku wzajemnego oddziaływania powstaje bezpośrednia relacja dwuosobowa „ja-ty”, jak również relacja „ja-my”, utożsamiająca uczestnictwo w zespole oraz aktywne współdziałanie, gdzie pracownicy dążą do realizacji nie tylko celów indywidualnych, ale także do osiągania korzyści zespołowych.

Relacje interpersonalne mogą mieć charakter ${ }^{14}$ :

- pozytywny - wówczas ujawniają się jako otwarcie na partnera, poszukiwanie z nim kontaktu oraz osiąganie wspólnych celów,

- negatywny - okazywane poprzez agresję, wrogość, obojętność, nienawiść, lekceważenie,

- obronny - wyrażające nieufność, podejrzliwość i lęk społeczny.

13 T. D. Allen, Personal Relationships, New York 2012, s. 16.

14lbidem, s. 47. 
Ewa Podlewska - Kompetencje menedżera ...

Istotę pozytywnych relacji można rozpatrywać jako porozumienie, będące podstawą skuteczności działania w różnych okolicznościach. Przejawia się ono jako proces o charakterze transakcyjnym, którego najważniejszą konsekwencję stanowi „wzajemny wpływ partnerów interakcji"15. Funkcjonując w środowisku zawodowym pracownicy bezustannie dzielą się informacjami, uzgadniają warunki wykonania zadań i podziału pracy, otrzymują polecenia lub je wydają ${ }^{16}$.

Kluczowymi determinantami pozytywnych relacji interpersonalnych są zaufanie, szacunek, życzliwość i wzajemność. Zaufanie warunkuje pewność co do dobrych intencji i motywów, jakimi kierują się współpracownicy, dzięki czemu członkowie zespołu polegają na swoich słowach, decyzjach i czynach ${ }^{17}$. Szacunek oznacza umiejętność dostrzeżenia mocnych stron drugiej osoby i służy wzmacnianiu jej poczucia własnej wartości, stanowiąc podstawę inteligencji stosunków międzyludzkich ${ }^{18}$. Okazywanie szacunku pozwala na wytworzenie osobistych więzi i sprawia, że partner odczuwa głęboką wspólnotę. Życzliwość z kolei stanowi wyraz przychylności i zrozumienia wobec oczekiwań innych, jak również świadczy o chęci udzielania pomocy. Wyraża przekonanie o konieczności odpowiedniego traktowania drugiej strony $w$ sytuacjach osobistych i biznesowych ${ }^{19}$. Istotne znaczenie posiada także wzajemność, oznaczająca dzielenie się informacjami, wiedzą i przekazywanie kompetencji. Stanowi również formę wyrażenia szacunku i uznania. Wzajemność pozytywnych relacji nie sygnalizuje ekwiwalentności wymiany, gdy zostaje wzbudzona po-

\footnotetext{
15 R. B. Adler, L. B. Rosenfeld, R. F. Proctor, Relacje interpersonalne, proces porozumiewania sie, Poznań 2011, s. 14.

${ }_{16}$ M. Bartkowiak, Kompetencje menedżera a relacje międzypracownicze $w$ organizacji uczącej się, Poznań 2011, s. 94.

17 D. J. McAllister, Affect and Cognition-Based Trust as Foundations for Interpersonal Cooperation In Organizations, „Academy of Management Journal” 1995, vol. 38 (1), s. 24-25.

18 S. F. Gross, Inteligencja stosunków międzyludzkich, Warszawa 1999, s.75.

19 J Aurifeille J.A., C.J. Medlin, Dimensions of Inter-firm Trust: Benevolence and Credibility, [w:] J. A. Aurifeille, C. J. MedlinC. Tisdelii (red.), Trust, Globlisation and Market Expansion, New York 2009, s.10.
} 
trzeba odwzajemniania, co prowadzi do efektywnego działania i wytworzenia sieci współzależności.

„Relacje interpersonalne w pracy mają duże znaczenie, ponieważ mogą wywrzeć silny wpływ na stosunki i zachowania pracowników"20. Determinują poziom rozwoju ludzi oraz nadają kierunek prawidłowemu funkcjonowaniu wewnętrznego i zewnętrznego środowiska pracy. Pozytywne relacje dają poczucie zadowolenia i satysfakcji, dzięki czemu wzmacniają "dobrostan psychiczny” i zachęcają do intensywnego działania. Proaktywne nastawienie do wykonywanej pracy powoduje, że pracownicy odczuwają mniejszy dyskomfort i wysiłek przy realizowaniu powierzonych zadań. Pozytywna relacja w miejscu pracy prowadzi zatem do poprawy zdrowia fizycznego i psychicznego, dzięki czemu „wspiera zdolność pracownika do zaangażowania się $\mathrm{w}$ pracę"21. Niezwykle ważne są relacje między przełożonymi a pracownikami. Ich pozytywny wymiar sprzyja wzrostowi innowacyjności oraz kreatywności. Badania empiryczne wskazują również na wpływ relacji interpersonalnych z przełożonymi na emocje pracowników, motywację, postawy i zdrowie ${ }^{22}$. Relacje na poziomie przełożony- pracownik wyznaczają kierunek dla sposobu i rodzaju interakcji tworzących się między pracownikami oraz określają stopień ich współpracy i współdziałania. Realizowanie wyznaczonych zadań w atmosferze zrozumienia, współpracy z pewnością prowadzi do wzrostu efektywności i pozwala ludziom dostrzec sens swojej pracy.

W bezpośrednich relacjach menedżer - podwładny to menedżer decyduje o rodzaju relacji, czy mają być tylko formalne czy także nieformalne. „Zatem odpowiedzialność za tworzenie się pozytywnych relacji z pracownikami zdecydowanie leży bardziej po stronie przeło-

20 T. D. Allen, Personal Relationships..., op. cit., s. 3.

${ }^{21}$ A. Glińska-Neweś, Employee interpersonal relationship, [w:] M. J. Stankiewicz (red.), Positive management Managing the Key Areas of Positive Organizational Potential for Company Success, Torun 2013, s. 129.

${ }^{22}$ M. Kalińska, The Role of middle managers in shaping positive Organizational potential, [w:] M. J. Stankiewicz (red.), Positive management Managing..., op. cit., s. 90 
Ewa Podlewska - Kompetencje menedżera ...

żonego 23". Menedżerowie kształtują środowisko pracy i doceniają pracowników, dostrzegają szanse i wyróżniają najlepszych. Są jest więc kreatorami ról, postaw i zachowań funkcjonujących w zespole. Ich wizerunek i postępowanie stanowią punkt odniesienia dla poczynań członków zespołu, dlatego powinni rozwijać i ciągle doskonalić własne kompetencje, które sprzyjają budowaniu pozytywnych relacji interpersonalnych.

\section{Cel badań}

Niniejszy artykuł dotyczy kompetencji menedżera, które sprzyjają budowaniu pozytywnych relacji interpersonalnych. Celem podjętych badań empirycznych przez autorkę było m.in. zidentyfikowanie tych kompetencji na podstawie analizy komparatywnej, zarówno z perspektywy menedżerów, jak i w kontekście oczekiwań pracowników.

\subsection{Metodyka badań i przebieg procesu badawczego}

Badanie empiryczne zostało przeprowadzone w 2016 roku na terenie województwa kujawsko-pomorskiego wśród menedżerów średniego szczebla i pracowników zatrudnionych w 31 przedsiębiorstwach (14 o profilu produkcyjnym, 11 usługowym i 6 handlowym). Dobór respondentów do próby nastąpił w sposób losowy, systematyczny. W procesie badawczym wzięło udział łącznie 391 respondentów, w tym 151 bezpośrednich przełożonych oraz 240 pracowników, a ich zadaniem było $\mathrm{m}$. in. dokonanie oceny istotności kompetencji menedżerów mających wpływ na kształtowanie pozytywnych relacji interpersonalnych. Klasyfikacji wskazanych kompetencji dokonano na podstawie literatury przedmiotu, własnych obserwacji oraz wyników wcześniej zrealizowanych badań.

Badanie przeprowadzono za pomocą ankiet (151 bezpośrednich przełożonych) oraz wywiadów indywidualnych, nieskategoryzowa-

23 T. D. Allen, Personal Relationships..., op. cit., s. 45. 
nych z kadrą kierowniczą (51 menedżerów) i 21 wywiadów focusowych z 240 pracownikami.

Kwestionariusze ankietowe składały się z pięciu punktów i metryczki, przy czym:

- Celem punktu pierwszego było wskazanie najistotniejszych zdaniem menedżerów cech $\mathrm{w}$ ich postawie i zachowaniu podczas codziennej pracy.

- Część druga dotyczyła podania najważniejszych celów realizowania obowiązków kierowniczych.

- Punkt trzeci prezentował efekty, mogące być wynikiem występowania pozytywnych relacji interpersonalnych $\mathrm{w}$ zespołach pracowniczych.

- Część czwarta oceniała preferencje menedżerów w zakresie narzędzi budowania pozytywnych relacji interpersonalnych.

- Piąty punkt ankiety zawierał opinię w zakresie zróżnicowanego pokoleniowo rynku pracy.

$\mathrm{Na}$ potrzeby niniejszego artykułu autorka wykorzystała punkt pierwszy kwestionariusza, w którym zastosowano metodę analizy struktury preferencji, polegającą na zaznaczeniu przez respondentów pięciu wybranych pozycji spośród czternastu podanych, zgodnie z ich wewnętrznym przekonaniem. Dzięki dokonanym wyborom zidentyfikowano preferencje menedżerów w zakresie istotnych ich zdaniem kompetencji.

Wywiady indywidualne zostały zrealizowane podczas osobistych kontaktów i zarejestrowane w formie pisemnej. Dopełniły one wyniki uzyskane na podstawie ankiet, jak również były wyrazem opinii o najważniejszych czynnikach kształtujących pozytywną atmosferę w zespole.

Wywiady focusowe z pracownikami zostały zrealizowane podczas osobistych spotkań grupowych i zarejestrowane w formie pisemnej. Specyfika metody zachęcała uczestników do otwartego przekazywania spostrzeżeń, umożliwiając uzyskanie odpowiedzi na problemy badawcze autorki. Spotkania grupowe zostały przeprowadzone na pod- 
Ewa Podlewska - Kompetencje menedżera ...

stawie scenariusza wywiadu, dzięki któremu poznano opinie, dotyczące m. in. oczekiwanych przez pracowników kompetencji bezpośredniego przełożonego podczas realizacji codziennych obowiązków.

Wszystkie przeprowadzone wywiady pozwoliły zdiagnozować okoliczności i uwarunkowania głoszonych poglądów oraz zidentyfikować podłoże prezentowanych postaw.

Uzyskane wyniki podczas procesu badawczego, a także poznane odczucia i spostrzeżenia w zakresie oczekiwań w zespole stanowiły bazę do wnioskowania i rekomendacji.

\subsection{Wyniki i wnioski z badania}

Na podstawie dokonanych wyborów przez menedżerów w punkcie pierwszym kwestionariusza ankiety, zidentyfikowano ich preferencje $\mathrm{w}$ zakresie istotnych kompetencji w codziennej pracy podczas pełnienia obowiązków kierowniczych.

Analizy statystycznej otrzymanych wyników dokonano na podstawie średnich arytmetycznych. Rysunek 1 odzwierciedla dane uzyskane podczas badania.

Wyniki badań pokazały, że najistotniejszą kompetencją dla menedżerów jest umiejętność komunikowania się (64\% wskazań) oraz wyznaczanie jasnych zasad w zespole (58\%). Warto zauważyć, że kobiety opowiedziały się za umiejętnością komunikowania się jako kluczową cechą w 75\%, natomiast mężczyźni jako priorytet uznali otwartość na poglądy i pomysły pracowników $62 \%$, a następnie podali umiejętność komunikowania się (58\%). Bezpośredni przełożeni wskazali jednostronne przekazywanie poleceń jako najmniej istotną kompetencję we współczesnym kierowaniu (4\%). Nisko ocenili także elastyczność w działaniu (18\%), co w turbulentnym i dynamicznie zmieniającym się otoczeniu powinno wzbudzać niepokój. 
Rysunek 1. Hierarchia kompetencji preferowanych przez menedżerów

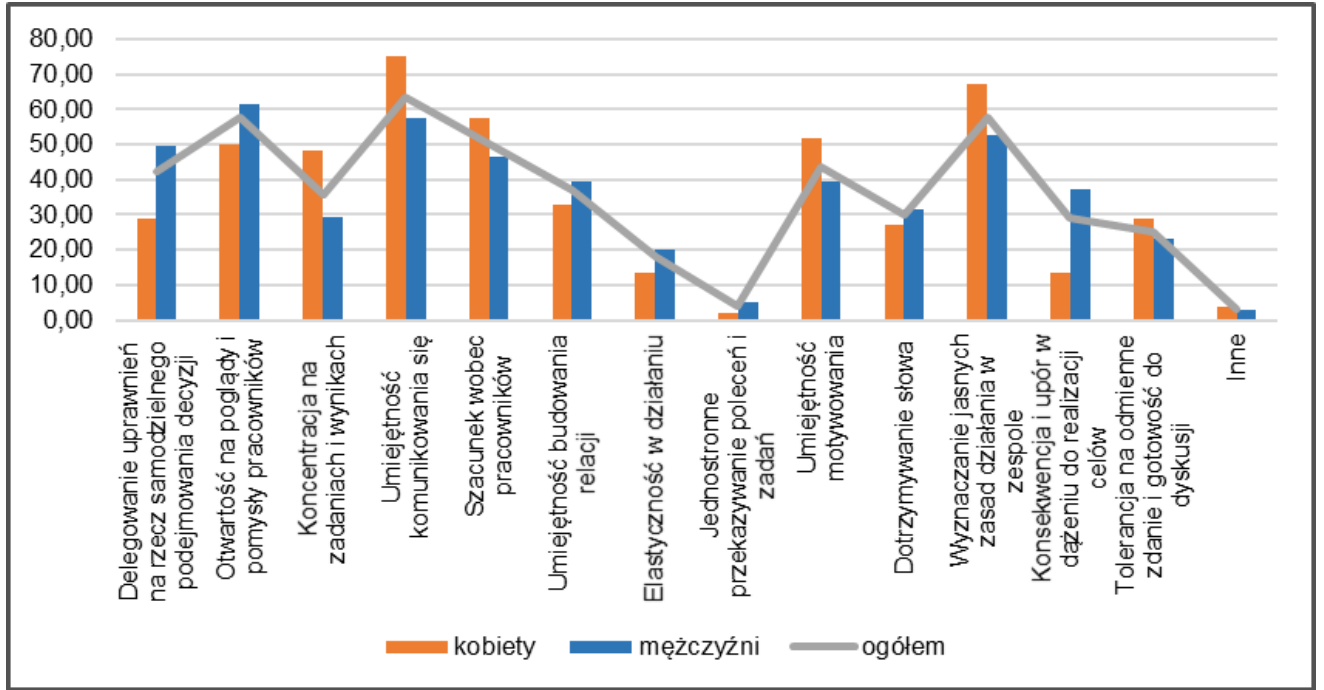

Źródło: opracowanie własne na podstawie przeprowadzonych badań w przedsiębiorstwach

Przeprowadzone wywiady indywidualne $\mathrm{z}$ menedżerami potwierdziły, że zdecydowanie opowiadają się oni za stylem zadaniowym w zarządzaniu, czyli można domniemać, że za nadrzędną kompetencję uznają wyznaczanie jasnych zasad działania $w$ zespole. Wprawdzie sprawna komunikacja zajęła drugą pozycję wśród wymienionych kompetencji, ale jej główny cel stanowi osiągnięcie wyników na wyznaczonym poziomie. Warto jednak zauważyć, że to budowanie pozytywnych relacji jest jednym z kluczowych środków prowadzących do pełnej realizacji zamierzeń.

$\mathrm{Na}$ podstawie wywiadów focusowych z pracownikami wykreowano profil menedżera XXI wieku oczekiwany przez podwładnych. Model zawiera istotne obszary niezbędne do zapewnienia satysfakcji pracowników i skutecznego wykonywania zadań. Respondenci wskazali najistotniejsze ich zdaniem kompetencje przełożonych, których oczekiwaliby, aby realizować powierzone zadania z pełnym zaangażo- 
waniem. Efekt odpowiedzi udzielonych przez pracowników podczas wywiadów odzwierciedla rysunek 2 .

Rysunek 2. Profil menedżera XXI wieku



Źródło: opracowanie własne na podstawie przeprowadzonych badań w przedsiębiorstwach

Wśród pożądanych kompetencji menedżera XXI wieku podanych przez pracowników, podstawą sprawnego funkcjonowania zarówno współczesnego menedżera, jak i całego zespołu jest wiedza i doświadczenie, które wzbudzają autorytet dając prawo do egzekwowania prawidłowej realizacji zadań.

Komunikacja i budowanie relacji oraz rozwijanie wartości, głównie szczerości, zaufania i szacunku są niewątpliwie wciąż aktualną i oczekiwaną kompetencją przełożonego. Ich zakres oddziaływania jest bardzo szeroki. Sprzyjają kreowaniu przyjaznego klimatu oraz warunkują posiadanie „ludzkiej twarzy” przez menedżera.

„Mój idealny menedżer jest dyplomatą" - zdanie przytoczone z wywiadów, dotyczy głównie jego zaangażowania w pracę zespołową 
i uczestnictwa w rozwiązywaniu problemów, a przejawia przede wszystkim w otwartości na poglądy i pomysły pracowników.

Profil „idealnego przełożonego” wskazuje kompetencje, które sprzyjają nie tylko budowaniu pozytywnych relacji, ale również dają szanse sprostania wymaganiom współczesności i nowoczesnego zarządzania.

\section{Podsumowanie}

Niniejszy artykuł miał na celu próbę uzupełnienia luki w zakresie kompetencji menedżerów niezbędnych w procesie budowania pozytywnych relacji interpersonalnych $w$ zespołach pracowniczych, jak również pożądanych przez pracowników w celu wyzwolenia w nich pełnego zaangażowania $\mathrm{w}$ realizowane czynności. Kształtowanie pozytywnych relacji nie jest zupełnie niedostrzeganym i niedocenianym obszarem w zarządzaniu, prym wiedzie jednak czynnik ekonomiczny, który może ulec zwielokrotnieniu, dzięki pozytywnych relacjom interpersonalnym pracowników. Zainteresowanie się więc tym zagadnieniem pozwoli zwiększyć osiągnięcia ekonomiczne przedsiębiorstwa, przede wszystkim poprzez wzrost lojalności oraz zaangażowania pracowników, będący wynikiem jakości wzajemnych relacji interpersonalnych ${ }^{24}$.

Świadomość dynamiczne zachodzących zmian gospodarczych i konieczność znajdowania dróg skutecznego działania czyni koniecznym doskonalenie kompetencji kadry zarządzającej w zakresie umiejętności interpersonalnych i komunikacyjnych.

W generalnej konkluzji z przeprowadzonych rozważań, należy zdaniem autorki zaznaczyć wagę profilu menedżera według prezentowanych kompetencji, których oczekują pracownicy. W perspektywie ponowoczesności prezentowanie odpowiednich kompetencji przez menedżera warunkuje sukces organizacji.

${ }^{24}$ M. Majcherczyk, Poczucie szczęścia z zaangażowanie pracowników, „Personel i Zarządzanie" 2015, nr 7, s.27. 
Ewa Podlewska - Kompetencje menedżera ...

Przedstawiony w artykule obszar zależności wzbudza zainteresowanie i wydaje się bardzo inspirujący, dlatego skłania autorkę do prowadzenia dalszych, pogłębionych badań w zakresie relacji interpersonalnych.

\section{Bibliografia:}

Adler R. B., Rosenfeld L. B.,. Proctor, R. F; Relacje interpersonalne, proces porozumiewania się, Wyd. Dom Wydawniczy Rebis, Poznań 2011.

Allen T. D., Personal Relationships, Routledge Taylor\&Francis Group New York London 2012.

Aurifeille J. A., Medlin C. J., Dimensions of Inter-firm Trust: Benevolence and Credibility, [w:] J. A. Aurifeille, C. J. Medlin, C. Tisdelii (red.), Trust, Globalization and Market Expansion, Nova Science Publisher Inc., New York 2009, s. 7-22.

Barnard C. H., Funkcje kierownicze, Wyd. Nowoczesność, Warszawa 1992.

Bartkowiak G., Psychologia w zarządzaniu, Wyd. Uniwersytetu Ekonomicznego w Poznaniu, Poznań 2010.

Bartkowiak M., Kompetencje menedżera a relacje międzypracownicze $w$ organizacji uczącej się, Wyd. Naukowe UAM, Poznań 2011.

Becker B. E., Huselid M.A., Ulrich D., Karta wyników zarzq̨dzania zasobami ludzkimi, Wyd. Oficyna Wolters Kluwer Business, Warszawa 2012.

Bednarz K., Skuteczny przywódca. Cechy decydujace o powodzeniu organizacji, [w:] M. Pawlak (red.), Nowe tendencje w zarzadzaniu - uwarunkowania społeczne, Wyd. KUL, Lublin 2013, s. 67-77.

Brilman J., Nowoczesne koncepcje i metody zarzqdzania, Polskie Wydawnictwo Ekonomiczne, Warszawa 2002.

Glińska-Neweś A., Employee interpersonal relationship, [w:] M. J. Stankiewicz (red.), Positive management Managing the Key Areas of Positive Organizational Potential for Company Success, Wyd. Dom Organizatora TNOiK, Toruń 2013, s. 125-154.

Gross S.F., Inteligencja stosunków międzyludzkich, Wyd. Agencja Wydawnicza Placet, Warszawa 1999. 
Guca S., Zmiany $w$ zarządzaniu i ich wpływ na kształtowanie się stosunków międzyludzkich, [w:] D. Lewicka, L. Zbiegień-Maciąg (red.), Wyzwania dla współczesnych organizacji w warunkach konkurencyjnej gospodarki, Wyd. AGH, Kraków 2010, s. 276-286.

Kalińska M., The Role of middle managers in shaping positive Organizational potential, [w:] Stankiewicz M. J. (red.), Positive management Managing the Key Areas of Positive Organizational Potential for Company Success, Wyd. Dom Organizatora TNOiK, Toruń 2013, s. 94-123.

Karna W., W poszukiwaniu tożsamości menedżera przyszłości, [w:] T. Listwan, S, Witkowski (red.), Sukces w zarzq̨dzaniu. Problemy organizacyjnozarządcze i psychospołeczne, Wyd. Akademii Ekonomicznej, Wrocław 2001, s. 185-193.

McAllister D. J., Affect and Cognition-Based Trust as Foundations for Interpersonal Cooperation In Organizations, „Academy of Management Journal” 1995 , vol. 38 (1), s. 20-28.

Majcherczyk M., Poczucie szczęścia z zaangażowanie pracowników, „Personel i Zarządzanie" 2015, nr 7, s. 24-27.

Podstawowe umiejętności przełożonego 2001, „Zarządzanie na Świecie” 2001, nr 2, 29-36.

Pszczołowski T., Organizacja od dołu i góry, Wyd. Państwowe Wydawnictwo Wiedza Powszechna, Warszawa 1978.

Rostkowski, Kompetencje a jakość zarzq̨dzania zasobami ludzkimi, [w:] A. Sajkiewicz (red.), Jakość zasobów pracy, Wyd. Poltext, Warszawa 2004.

Tyrańska M., Współczesne tendencje w zarządzaniu zasobami ludzkimi, Wyd. Difin, Warszawa 2010.

Tyrańska (red.), Współczesne tendencje w zarzq̨dzaniu zasobami ludzkimi w przedsiębiorstwie, Wyd. Difin, Warszawa 2011. 